\title{
Optimalisasi Penggunaan Google Form terhadap Pembelajaran Matematika
}

\author{
Dwi Parinata ${ }^{\left.{ }^{*}\right)}$, Nicky Dwi Puspaningtyas ${ }^{2}$ \\ ${ }^{1,2}$ Universitas Teknokrat Indonesia \\ *dwiparinata52@gmail.com
}

\begin{abstract}
Abstrak
Tujuan dari penelitian ini adalah untuk mengoptimalkan penggunaan media pembelajaran Online (e-learning) dengan sebuah aplikasi berbasis web bernama Google Form yang bertujuan untuk memberikan pemahaman khususnya pelajar dalam proses pembelajaran Matematika sehingga tugas maupun ujian dapat dilakukan secara Online. Penelitian ini menggunakan jenis penelitian kualitatif. Subjek penelitian ini adalah siswa kelas 5 SD Al-Kautsar Bandar Lampung, sebanyak 19 orang. Penelitian ini dilakukan dalam 4 tahap yakni; 1) Penyebaran tes kuis pemecahan masalah dan kuesioner dalam bentuk Google Form, 2) Melakukan penilaian terhadap hasil jawaban siswa kelas 5 SD Al-Kautsar Bandar Lampung menggunakan skala Guttman, 3) Menguji validitas dengan teknik korelasi product moment dan reliabilitas dengan metode Chronbach's Alpha, 4) interpretasi hasil perhitungan. Kesimpulan dari penelitian ini adalah pada kuisioner ketercapaian indikator menghasilkan 54\% negatif serta $57 \%$ positif terhadap proses pengoptimalisasi media online Google Form hal ini menunjukkan bahwa media online yang berupa Google Form menjadi acuan yang Cukup Tinggi dalam menangani permasalahan belajar secara online (e-learning).
\end{abstract}

Kata kunci: Google Form, Matematika, Optimalisasi.

\section{Abstract}

The purpose of this research is to optimize the use of online learning media (e-learning) with a web-based application called Google Form. which aims to provide understanding, especially students in the Mathematics learning process so that assignments and exams can be done online. This research uses qualitative research. The subjects of this research were 19 students of grade 5 SD Al-Kautsar Bandar Lampung. This research was conducted in 4 stages, namely; 1) Distribution of problem-solving quiz tests and questionnaires in the form of Google Form, 2) Assessing the results of the 5th grade students' answers at Al-Kautsar Elementary School Bandar Lampung using the Guttman scale, 3) Testing the validity with the product moment correlation technique and reliability using the Chronbach's Alpha method, 4) interpretation of calculation results. The conclusion of this research is that the indicator achievement questionnaire produces $54 \%$ negative and $57 \%$ positive impact on the Google Form online media optimization process, this shows that online media in the form of Google Form is a fairly high reference in dealing with online learning problems (e-learning).

Keywords: Google Form, Mathematics, Optimization.

\section{Pendahuluan}

Kebutuhan akan teknologi pada dunia pendidikan di Indonesia, merupakan bagian yang tidak terpisahkan dari kebutuhan hidup masyarakat sehari-hari, seiring dengan pesatnya media-media pembelajaran yang telah diciptakan, dunia pendidikan selalu mengalami proses perubahan yang secara tidak langsung dipengaruhi oleh ilmu pengetahuan dan teknologi. Menanggapi era kemajuan teknologi pada saat ini, pendidikan 
harus lebih menyesuaikan dengan perkembangan teknologi yang semakin canggih untuk mencapai tujuan yaitu memudahkan pelaksanaan pendidikan, khususnya pada saat seorang pengajar atau pelajar pada proses pembelajaran dalam menguasai mata pelajaran matematika. (Siagian \& Daut, 2016) mendefinisikan matematika sebagai ilmu yang membahas pola atau keteraturan (pattern) dan tingkatan (order). Untuk itu guru matematika harus menyediakan fasilitas siswanya dalam proses pembelajaran melalui keteraturan (pattern) yang ada, menurutnya kemampuan siswa dalam koneksi matematika masih rendah. Rendahnya kemampuan koneksi matematik siswa akan mempengaruhi kualitas belajar siswa itu sendiri yang berdampak pada rendahnya prestasi di sekolah. Dengan demikian media online bisa sangat membantu di masa seperti saat ini. Pembelajaran online adalah pembelajaran yang diselenggarakan melalui jejaring web dimana seorang guru menyediakan materi dalam bentuk rekaman video atau Slideshow dengan disertai tugas-tugas baik dalam bentuk tulisan maupun bergambar, (Djamilah\&Lazwardi, 2020). salah satu web yang mudah diakses, sederhana, dan cukup baik untuk dikembangkan sebagai alat untuk para pengajar maupun pelajar pada proses pembelajaran yakni Google Form.

Terkhusus untuk seorang pengajar sebelum mengoprasikan Google Form syaratnya adalah harus memiliki akun universal Google, yakni dengan mendaftar pada http://account.Google.com/login. Google Form adalah situs yang berbasis web dengan demikian setiap orang dapat memberikan tanggapan atau jawaban terhadap kuis ataupun kuisioner secara cepat dimanapun ia berada dengan menggunakan aplikasi internet komputer/laptop ataupun Handphone. Karenanya, dengan menggunakan web ini maka seorang guru atau profesi lainnya yang berhubungan dengan internet tidak perlu menggunakan kertas lagi untuk mencetak kuis atau kuisionernya. menghemat waktu baik dalam membagikan, mengumpulkan kembali dan menganalisis hasil kuis dan angketnya. Dengan demikian dapat disimpulkan bahwa Google Form sangat sesuai digunakan untuk mengumpulkan pendapat orang yang berjauhan, mengelola pendaftaran acara atau sekolah melalui internet, mengumpulkan sebuah data, membuat kuis dadakan, mengulas soal lebih sederhana, dan lain sebagainya (Bulan \& Zainiyati, 2020).

Adapun beberapa keunggulan pembuatan penilaian pada proses pembelajaran menggunaka Google Form adalah: 1) Tampilan Form yang menarik. Web ini menyediakan berbagai fasilitas untung para penggunanya seperti profil berupa nama, foto dan lainnya. Google Form juga memiliki banyak template yang membuat kuis dan kuesioner Online 
tersebut semakin menarik dan berwarna. 2) Memiliki berbagai jenis tes yang bebas dipilih. web ini menyediakan fasilitas pilihan tes yang bebas digunakan sesuai dengan keperluan pengguna. Seperti jawaban pilihan ganda, ceklis, tarikturun, skala linier, dan lain lainnnya. bisa juga menambahkan gambar dan video YouTube ke dalam kuis. 3) Responden dapat memberikan tanggapan dengan cepat dimanapun keberadaannya. dan dapat digunakan oleh setiap orang secara gratis untuk membuat kuisioner Online dan kuis Online menggunakan laptop atau handphone yang terhubung dengan internet lalu membagikan alamat link formnya. Responden dapat memberikan tanggapan dimanapun dan kapanpun dengan membuka alamat web atau link yang dibagikan. Semua tanggapan dan jawaban orang lain akan secara otomatis ditampung, disusun, serta disimpan oleh aplikasi Google Form dengan cepat dan aman. 4) Formulir Google Form begitu responsive. Berbagai jenis kuis dan kuesioner dapat dibuat dengan mudah, lancar dan hasilnya tampak profesional. 5) Hasil akan secara otomatis tersusun. Tanggapan survei dikumpulkan dalam formulir dengan otomatis dan rapih, disertai dengan info tanggapan waktu nyata dan grafik hasil tanggapan. 6) Bisa dikerjakan bersama dengan orang lain. Kuesioner dan kuis menggunakan Google Form dapat dikerjakan bersama orang lain atau siapa saja yang diinginkan oleh pengguna (Batubara, 2016).

Terdapat beberapa fungsi Google Form untuk dunia pendidikaan sebagai berikut: a) Memberikan tugas latihan atau ulangan online melalui laman Website, b) Mengumpulkan pendapat orang lain melalui laman Website, c) Mengumpulkan berbagai data siswa maupun guru melalui halaman Website, d) Membuat formulir pendaftaran online untuk sekolah, e) Membagikan kuesioner kepada orang-orang secara online. Penggunaan mediamedia online dalam pendidikan saat ini sangatlah banyak, dengan adanya media belajar secara online sangat berpengaruh penting di era saat ini terutama pada saat pandemi covid19 yang sedang terjadi. Namun masih banyak hal yang kurang diperhatikan dimana masyarakat masih merasa canggung bahkan bingung mengolah dan menggunakan mediamedia online tersebut, dengan menngunakan Google Form masyarakat akan lebih mudah memahaminya dikarnakan cara serta penyajiannya yang simpel dan tidak terkesa rumit untuk diakses terutapa bagi seorang pengajar atau pelajar yang akan mnggunakannya.tidak hanya menngunakan Google Form saja namun masih banyak web atupun aplikasi yang mudah dipelajari dan digunakan untuk menunjang proses pembelajaran (Batubara, 2016).

Tujuan dari penelitian ini adalah untuk mengoptimalkan penggunaan media pembelajaran Online (e-learning) dengan sebuah aplikasi berbasis web bernama Google 
Form. yang bertujuan untuk memberikan pemahaman khususnya pelajar dalam proses pembelajaran Matematika sehingga tugas maupun ujian dapat dilakukan secara Online.

\section{Metode Penelitian}

Sesuai dengan tujuan penelitian dalam melakukan penelitian ini adalah untuk mengoptimalkan penggunaan Google Form terhadap pembelajaran matematika. Jenis penelitian yang digunakan yakni penelitian kualitatif. Metode penelitian kualitatif merupakan suatu pendekatan dalam melakukan penelitian yang berorientasi pada fenomena atau gejala yang bersifat alami (Nurani, dkk, 2020). Subjek penelitian ini adalah siswa kelas 5 SD Al-Kautsar Bandar Lampung, sebanyak 19 orang. Penelitian ini dilakukan dalam 4 tahap yakni; 1) Penyebaran tes kuis pemecahan masalah dan kuesioner dalam bentuk Google Form, 2) Melakukan penilaian terhadap hasil jawaban siswa kelas 5 SD Al-Kautsar Bandar Lampung menggunakan skala Guttman, 3) Menguji validitas dengan teknik korelasi product moment dan reliabilitas dengan metode Chronbach's Alpha, 4) interpretasi hasil perhitungan.

Adapun pengumpulan data didapat dari tes kuis pemecahan masalah dengan materi berupa pecahan yang banyak menggunakan soal bergambar, berisi 10 soal pilihan ganda. Selanjutnya peneliti melakukan penyebaran kuisioner diterdiri dari 15 pernyataan dengan opsi jawaban setuju, tidak setuju. Adapun indikator dari kuesioner terdiri dari 3 indikator yaitu sebagai berikut; 1) respon siswa dalam kemudahan mengakses web Google Form, 2) keefektifan penggunaan aplikasi Google Form dalam pembelajaran daring, 3) Penggunaan Google Form dalam pembelajaran. Seluruh proses pemberian soal dan kuesioner dilaksanakan secara online pada web Google Form. Berikut disajikan indikator kuisioner dan instrumen butir pertanyaan pada Google Form. 
Tabel 1. Indikator pada tiap butir pertanyaan kuesioner.

\begin{tabular}{|l|l|c|c|}
\hline \multirow{2}{*}{ No. } & \multicolumn{1}{|c|}{ Indikator } & \multicolumn{2}{|c|}{$\begin{array}{c}\text { Nomor Butir } \\
\text { Pertanyaan }\end{array}$} \\
\cline { 2 - 4 } & \multicolumn{1}{|c|}{$(-)$} & $(+)$ \\
\hline 1. & $\begin{array}{l}\text { Respon siswa dalam kemudahan } \\
\text { mengakses web Google Form }\end{array}$ & $2,4,7$ & 1,5 \\
\hline 2. & $\begin{array}{l}\text { Keefektifan penggunaan aplikasi Google } \\
\text { Form dalam pembelajaran daring }\end{array}$ & 3,6 & $8,10,12$, \\
\hline 3. & $\begin{array}{l}\text { Penggunaan Google Form dalam } \\
\text { pembelajaran }\end{array}$ & 9,11 & $13,14,15$ \\
\hline \multicolumn{2}{|c|}{ Total } & $\mathbf{1 5}$ \\
\hline
\end{tabular}

Butir pertanyaan pada kuesioner diuji validitasnya dengan metode korelasi Product moment, dimana nilai rtabel dengan 19 responden pada signifikasi 5\% sebesar 0,3687. Dari perhitungan yang telah dilakukan, didapat bahwa rhitung >rtabel yang menandakan kuesioner valid. Setelah uji validitas, instrumen pertanyaan kembali diuji reliabilitas memakai metode Cronbach Alpha. Perhitungan dilakukan menggunakan Laptop dengan Aplikasi SPSS (PASW Statistic 18).

Penilaian kuesioner menggunakan skala Guttman untuk mempermudah peneliti dalam menentukan optimalisasi penggunaan Google Form terhadap pembelajaran matematika. Skala Guttman adalah skala yang hanya menyediakan dua pilihan jawaban, misalnya ya-tidak, baik-jelek, pernah-belum pernah, dan lain-lain (Fatimah \& Puspaningtyas, 2020). Skala ini menghasilkan binary skor (0-1) dimana jawaban hanya diberi skor 1 jika benar/positif dan 0 jika salah.

\section{Hasil dan Pembahasan}

Pada tahap awal peneliti melakukan penyebaran tes kuis pemecahan masalah dan kuesioner dalam bentuk Google Form kepada siswa kelas 5 SD Al-Kautsar Bandar Lampung, dimana tes kuis pemecahan masalah terdiri dari 10 soal pilihan ganda dengan banyak soal bergambar sedangkan untuk kuisioner terdiri dari 15 soal dengan opsi jawaban setu atau tidak setuju, peneliti memberikan pada subjek dalam bentuk link Google Form. Pada tahap ke 2 peneliti melakukan penilaian terhadap hasil jawaban siswa kelas 5 SD AlKautsar Bandar Lampung menggunakan .Skala yang digunakan untuk penilaian kuesioner ini adalah Skala Guttman. 
Pada tahapan ketiga peneliti melakukan pengujian validitas dan reliabilitas. Validitas dilakukan dengan mengorelasikan skor tiap butir pertanyaan dengan skor total (jumlah skor tiap butir pertanyaan) menggunakan teknik korelasi product moment. Serta menguji validitas pada tiap butir pertanyaan, semakin tinggi tingkat validitas maka instrumen layak untuk digunakan. Sebaliknya, jika nilai validitas semakin rendah maka instrumen tidak dapat digunakan. Suatu instrumen dikatakan valid jika rhitung > rtabel (Fatimah \& Puspaningtyas, 2020) Dari perhitungan yang telah dilakukan, didapat bahwa rhitung > rtabel yang menandakan kuesioner valid. Setelah uji validitas, instrumen pertanyaan kembali diuji reliabilitas memakai metode Cronbach Alpha., pada tahapan ke 4 peneliti melakukan interpretasi hasil perhitungan. Berikut gambaran tes kuis dan hasil perhitungan uji reliabilitas tes kuis pemecahan masalah dan kuisioner yang dilakukan pada aplikasi SPSS (PASW Statistic 18).

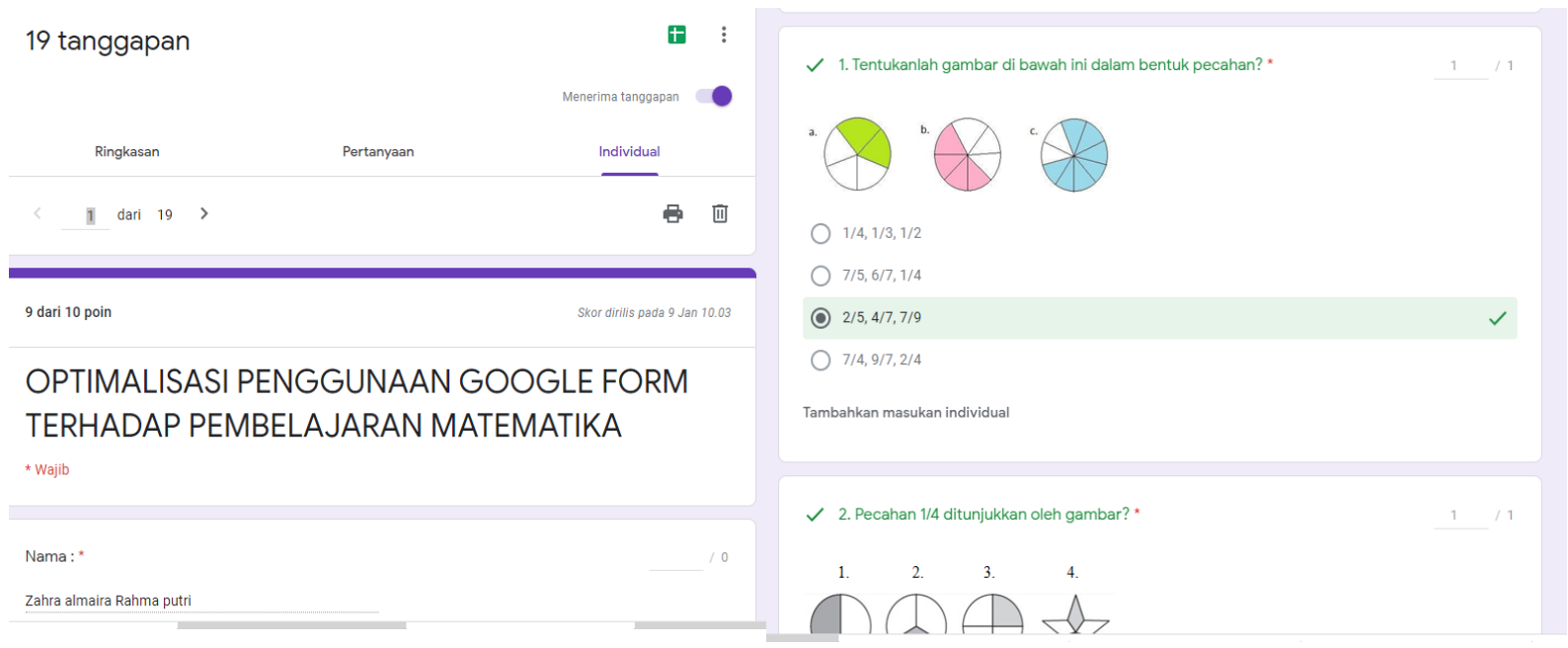

Gambar 1. Tes Kuis melalui Google Form

Tabel 2. Hasil Perhitungan Uji Reliabilitas Kuisioner

\begin{tabular}{|c|c|c|c|}
\hline \multicolumn{4}{|c|}{ Case Processing Summary } \\
\hline \multicolumn{2}{|c|}{} & $\mathrm{N}$ & $\%$ \\
\hline \multirow{4}{*}{ Cases } & Valid & 19 & 100,0 \\
\cline { 2 - 4 } & Excluded $^{\mathrm{a}}$ & 0 &, 0 \\
\cline { 2 - 4 } & Total & 19 & 100,0 \\
\hline Cronbach's Alpha & \multicolumn{2}{c|}{ Nof items } \\
\hline \multicolumn{2}{|c|}{, 736} & \multicolumn{2}{c|}{15} \\
\hline
\end{tabular}

Dari tabel diatas, terlihat bahwa nilai Cronbach Alpha sebesar 0,736 dengan $n$ of item atau jumlah item pertanyaan kuis 10 serta kuesioner sebanyak 15 pertanyaan. Dapat 
dikatakan bahwa kuesioner yang digunakan dalam penelitian valid karena nilai Cronbach Alpha $>0,6$. Hasil perhitungan uji reliabilitas dan perhitungan ketercapaian indikator pada Kuesioner dapat diinterpretasikan dalam kriteria Guilford di bawah ini.

Tabel 3. Kriteria Guilford pada Hasil Uji Reliabilitas

\begin{tabular}{|c|c|c|}
\hline No. & Koefisien Korelasi & Kualifikasi \\
\hline 1 & $0,91-1,00$ & Sangat Tinggi \\
\hline 2 & $0,71-0,90$ & Tinggi \\
\hline 3 & $0,41-0,70$ & Cukup Tinggi \\
\hline 4 & $0,21-0,40$ & Rendah \\
\hline 5 & Negatif $-0,20$ & Sangat Rendah \\
\hline
\end{tabular}

Kriteria Guilford dikualifikasikan dengan 5 kategori yakni sangat rendah, rendah, cukup tinggi, tinggi dan sangat tinggi. Kuis diperuntukkan untuk melengkapi data pada penelitian yang berupa tes kuis berisikan soal bergambar serta hasil Kuesioner Optimalisasi Penggunaan Google Form terhadap Pembelajaran Matematikan memperoleh kualifikasi Tinggi dengan hasil perhitungan reliabilitas menggunakan Cronbach Alpha sebesar 0,736 .

Perhitungan pada kuesioner Optimalisasi Penggunaan Google Form terhadap Pembelajaran Matematikan dilakukan untuk mengetahui ketercapaian indicator, maka dilakukan perhitungan pada tiap butir pertanyaan yang diajukan.

Tabel 4. Hasil Perhitungan Ketercapaian Indikator pada Kuesioner

\begin{tabular}{|c|c|c|c|c|c|c|c|}
\hline \multirow[t]{2}{*}{ No. } & \multirow[t]{2}{*}{ Indikator Kebiasaan Belajar } & \multicolumn{2}{|c|}{ Skor Dicapai } & \multicolumn{2}{|c|}{$\begin{array}{c}\text { Skor } \\
\text { Maksimum }\end{array}$} & \multicolumn{2}{|c|}{$\begin{array}{c}\text { Ketercapaian } \\
(\%)\end{array}$} \\
\hline & & $(-)$ & $(+)$ & $(-)$ & $(+)$ & $(-)$ & $(+)$ \\
\hline 1. & $\begin{array}{l}\text { Respon siswa dalam kemudahan } \\
\text { mengakses web Google Form }\end{array}$ & 29 & 22 & 57 & 38 & 51 & 58 \\
\hline 2. & $\begin{array}{l}\text { Keefektifan penggunaan aplikasi } \\
\text { Google Form dalam } \\
\text { pembelajaran daring }\end{array}$ & 23 & 27 & 38 & 57 & 61 & 47 \\
\hline 3. & $\begin{array}{l}\text { Penggunaan Google Form dalam } \\
\text { pembelajaran }\end{array}$ & 19 & 37 & 38 & 57 & 50 & 65 \\
\hline \multicolumn{6}{|c|}{ Rata-rata ketercapaian } & 54 & 57 \\
\hline
\end{tabular}

Pada perhitungan yang telah dilakukan, terdapat dampak ketercapaian indikator. Dampak tersebut dibagi menjadi dua yakni, dampak positif dan dampak negative. Terlihat 
bagian pertama dampak negatif sebesar $51 \%$ dan dampak positif sebesar $58 \%$ respon siswa dalam kemudahan mengakses web Google Form hal ini menunjukkan bahwa persentase respon siswa dalam kemudahan mengakses web Google Form cukup baik dimana persentase positif lebih besar dari persentase negatif. Kemungkinan kendala siswa dalam mengakses Google Form adalah kesuliatan mereka saat kuota internet sudah habis atau bahkan jaringan internet yang digunakan banyak mengalami gangguan dan sebagainya, pernyataan ini sesuai dengan (Fatimah \& Puspaningtyas, 2020) yang mengatakan bahwa pengalihan metode tersebut menyebabkan banyak kendala salah satunya siswa harus mengeluarkan biaya cukup mahal untuk membeli kuota data internet. Sedangkan kemudahan siswa dalam mengakses Google Form yakni dalam pengoperasian Google Form itu sendiri tidaklah rumit dimana sederhana dan mudah dipahami.

Untuk hasil perhitungan ketercapaian pada indikator yang ke dua diperoleh yakni sebanyak $61 \%$ negatif dan $47 \%$ positif terhadap keefektifan penggunaan aplikasi Google Form dalam pembelajaran daring. Hasil perhitungan menyatakan bahwa angka negatif lebih tinggi dari positif, dimana mayoritas peserta didik mengeluhkan tidak efektifnya proses pembelajaran ketika mode daring dan juga mengeluhkan mengenai penggunaan kuota internet serta signal internet yang dianggap masih belum memadai di beberapa tempat, namun terdapat hal menarik pada fakta tersebut, permasalahan utama pada pembelajaran daring utamanya terletak pada permasalahan teknis, sehingga apabila permasalahan teknis tersebut dapat teratasi, pembelajaran daring seharusnya minimal memberikan efek yang sama dengan pembelajaran secara konvensional (Maskar, Dewi, \& Puspaningtyas, 2020).

Selanjutnya pada perhitungan ketercapaian pada indikator yang ketiga, terlihat bahwa $50 \%$ negatif dan $65 \%$ positif terhadap proses penggunaan Google Form dalam pembelajaran berdaskan persentase yang telah diperhitungkan, media online Google Form sangat mudah untuk digunakan dalam pembelajaran secara online (daring). (Puspaningtyas\&Dewi) menyatakan pada penelitiannya bahwa, pembelajaran daring dapat meningkatkan motivasi siswa dalam pembelajaran dikarenakan memberikan kesempatan untuk berinteraksi dengan teknologi. Dimasa tahun 2019-2021 masih terjadinya sebuah wabah dimana banyak memakan korban disebut dengan penyakit menular yakni corona virus yang menyebabkan dampak bagi dunia pendidikan, saat ini siswa harus belajar dirumah mereka masing-masing. sekarang kegiatan yang bernama sekolah berhenti dengan tiba-tiba karena gangguan corona virus (Covid-19). Sejauh mana dampaknya bagi proses 
Belajar di sekolah? Khusus untuk Indonesia banyak bukti ketika sekolah sangat mempengaruhi produktivitas dan pertumbuhan ekonomi, karena hal tersebut mereka mengunkan media agar pembelajaran tetap terlaksana dengan baik (Parnabhakti\& Puspaningtyas, 2020).

Tahap yang terakhir merupakan rata-rata ketercapaian pada indikator ketercapaian yang menghasilkan sebanyak 54\% negatif serta $57 \%$ positif, terhadap proses pengoptimalisasi media online Google Form hal ini menunjukkan bahwa media online yang berupa Google Form menjadi acuan yang cukup tinggi dalam menangani permasalahan belajar secara online (e-learning).

\section{Simpulan}

Dari penelitian ini, dapat disimpulkan bahwa Kuesioner Optimalisasi Penggunaan Google Form terhadap Pembelajaran Matematikan memperoleh tingkat kevalitan Tinggi dengan hasil perhitungan reliabilitas menggunakan Cronbach Alpha sebesar 0,736. Serta pada kuisioner ketercapaian indikator menghasilkan sebanyak 54\% negatif serta 57\% positif, terhadap proses pengoptimalisasi media online Google Form hal ini menunjukkan bahwa media online yang berupa Google Form menjadi acuan yang cukup tinggi dalam menangani permasalahan belajar secara online (e-learning). Dengan demikian dapat dikatakan bahwa penggunaan media online berupa Google Form cukup membantu siswa kelas 5 SD Al-Kautsar Bandar Lampung dalam penyelesaian permasalahan matematika serta berdasarkan kuisioner yang telah diberi bahwa ketertarikan siswa kelas 5 SD AlKautsar Bandar Lampung cukup baik.

Saran yang dapat diberikan yakni dengan adanya media online yang sangat banyak, baik berupa Google Form maupun media online lainnya hendaknya sebagai pelajar, pengajar maupun jenis pekerjaan apapun yang berhubungan dengan kegiatan online maka kita harus sebaik mungkin dalam mengolah serta memanfaatkannya sebagai alat penunjang pengajaran yang kita jalani dan terutama bagi pelajar dalam menguasai mata pelajaran matematika melalui Google Form secara maksimal. 


\section{Referensi}

Batubara, H.H. (2016). Penggunaan google form sebagai alat penilaian kinerja dosen di Prodi PGMI Uniska Muhammad Arsyad Al Banjari. Al-Bidayah: Jurnal Pendidikan Dasar Islam, 8(1), 39-50.

Bulan, S., \& Zainiyati, H.S. Pembelajaran Online Berbasis Media Google Formulir dalam Tanggap Work From Home Masa Pandemi Covid-19 di Madrasah Ibtidaiyah Negeri (MIN) 1 Paser. Syamil: Jurnal Pendidikan Agama Islam, 8(1), 15-34.

Djamilah, S., \& Lazwardi, A. (2020). Pembelajaran Daring Struktur Aljabar Dan Analisis Real Pada Masa Pandemi. Jartika: Jurnal Riset Teknologi Dan Inovasi Pendidikan,3(2), 403-409.

Fatimah, C. \& Puspaningtyas, N.D. (2020). Dampak Pandemi Covid-19 terhadap Pembelajaran Online Mata Pelajaran Matematika di MAN 1 Lampung Selatan. Jurnal Pendidikan Matematika UNILA, 8(4), 250-260.

Maskar, S., Dewi, P.S. \& Puspaningtyas, N.D. (2020). Online Learning \& Blended Learning: Perbandingan Hasil Belajar Metode Daring Penuh dan Terpadu. PRISMA 9(2), 154-166.

Nurani, U., Sulistiani, I.R. \& Dewi, M.S. (2020). Pengelolaan Kelas Guru Dalam Pembelajaran Matematika. JPMI: Jurnal Pendidikan Madrasah Ibtidaiyah, 2(3), 143-147.

Parnabhakti, L., \& Puspaningtyas, N.D. (2020). Penerapan Media Pembelajaran Powerpoint melalui Google Classroom untuk Meningkatkan Hasil Belajar Siswa. JIMR: Jurnal Ilmiah Matematika Realistik, 1(2), 8-12.

Puspaningtyas, N.D. 2019. Berpikir Lateral Siswa SD dalam Pembelajaran Matematika. Mathema: Jurnal Pendidikan Matematika, 1(1), 24-30.

Puspaningtyas, N.D., \& Dewi, P.S. (2020). Persepsi Peserta Didik terhadap Pembelajaran Berbasis Daring.JPMI: Jurnal Pembelajaran Matematika Inovatif, 3(6), 703-712.

Sarmini, Pandanarum, P., \& Permanasari, D.A. (2020). Pelatihan Google Apps For Education Kepada Guru Madrasah Aliyah (MA) Tanbihul Ghofiliin Banjarnegara.Selaparang: Jurnal Pengabdian Masyarakat Berkemajuan, 4(1), 437441.

Siagian, M.D. (2016). Kemampuan Koneksi Matematik dalam Pembelajaran Matematika. MES: Journal of Mathematics Education and Science, 2(1), 58-67.

Suhada, I., Kurniati, T., Pramadi, A., \& Listiawati, M. (2020). Pembelajaran Daring Berbasis Google Classroom Mahasiswa Pendidikan Biologi Pada Masa Wabah Covid-19. Digital Library UIN Sunan Gunung Djati, 1-10.

Tumengkol, A. A. (2020). Pengalaman Pembelajaran Berbasis Blended Learning Mata Kuliah Ilmu Alamiah Dasar Menggunakan Google Classroom Pada Mahasiswa Geografi. Jurnal Episentrum, 1(1), 39-43.

Ulfa, M. (2019). Strategi Pre-View, Question, Read, Reflect, Recite, Review (PQ4R) Pada Pemahaman Konsep Matematika. Mathema: Jurnal Pendidikan Matematika, 1(1): 48-55. 